\title{
Clinical and hematological findings in Leishmania braziliensis-infected dogs from Pernambuco, Brazil
}

\author{
Achados clínicos e hematológicos em cães infectados por Leishmania braziliensis de Pernambuco, Brasil \\ Luciana Aguiar Figueredo ${ }^{1}$; Milena de Paiva-Cavalcanti ${ }^{1}$; Ericka Lima Almeida ${ }^{1}$; \\ Sinval Pinto Brandão-Filho' ${ }^{1}$; Filipe Dantas-Torres ${ }^{1,2 *}$
}

${ }^{1}$ Departamento de Imunologia, Centro de Pesquisas Aggeu Magalhães - CPqAM, Recife, PE, Brasil

${ }^{2}$ Dipartimento di Medicina Veterinaria, Università degli Studi di Bari - UNIBA, Valenzano, BA, Itália

Received February 9, 2012

Accepted May 28, 2012

\begin{abstract}
Canine cutaneous leishmaniasis by Leishmania braziliensis is a neglected, but widespread disease of dogs in South America. This paper describes clinical and hematological alterations in 17 L. braziliensis-infected dogs from Brazil. The most common hematological findings were thrombocytopenia (82.4\%), anemia (70.6\%), low packed cell volume (52.9\%) and eosinophilia (41.2\%). Twelve (70.6\%) dogs displayed at least one evident physical alteration; 11 dogs (64.7\%) presented skin lesions, four (23.5\%) had weight loss and two (11.8\%) onychogryphosis. L. braziliensis-infected dogs present clinical and hematological signs often observed in dogs infected by other pathogens. This indicates that veterinarians and public health workers should not consider the presence of non-specific clinical signs as diagnostic criteria for visceral leishmaniasis in dogs living endemic areas to avoid misdiagnosis and subsequent elimination of dogs infected by $L$. braziliensis.
\end{abstract}

Keywords: Leishmania braziliensis, dogs, Pernambuco, Brazil.

\section{Resumo}

A leishmaniose cutânea canina causada por Leishmania braziliensis é uma doença negligenciada, mas disseminada entre cães na America do Sul. Este artigo descreve alteraçóes clínicas e hematológicas em 17 cães infectados por L. braziliensis do Brasil. As alteraçóes hematológicas mais comuns foram trombocitopenia (82,4\%), anemia (70,6\%), baixo valor de hematócrito $(52,9 \%)$ e eosinofilia $(41,2 \%)$. Doze $(70,6 \%)$ cães apresentaram pelo menos uma alteração física; $11(64,7 \%)$ apresentaram lesóes cutâneas, quatro (23,5\%) perda de peso e dois $(11,8 \%)$ onicogrifose. Cães infectados por L. braziliensis apresentaram alteraçóes clínicas e hematológicas inespecíficas que sáo comumente observadas em cães infectados por outros patógenos. Isso indica que veterinários e profissionais de saúde pública não deveriam considerar a presença de tais sinais clínicos como critério de diagnóstico para leishmaniose visceral em cães, em áreas endêmicas, no intuito de evitar um diagnóstico equivocado e a subsequente eliminação de cães infectados por L. braziliensis.

Palavras-chave: Leishmania braziliensis, cães, Pernambuco, Brasil.

Canine cutaneous leishmaniasis is a widespread disease affecting dogs caused by different species of Leishmania parasites. In South America, Leishmania braziliensis is the most widespread causative agent (DANTAS-TORRES, 2009). The disease in dogs is characterized by local, self-healing ulcerative lesions on the ears, scrotum, feet, nipples, and muzzle (PIRMEZ et al., 1988; MADEIRA et al., 2003). However, canine cutaneous leishmaniasis is a neglected disease, mainly because most of the cases occur

*Corresponding author: Filipe Dantas-Torres

Departamento de Imunologia, Centro de Pesquisas Aggeu Magalhães,

Fundação Oswaldo Cruz - Fiocruz, Av. Prof. Moraes Rego, s/n,

Cidade Universitária, CEP 50670-420, Recife, PE, Brasil

e-mail: filipe.vet@globo.com far away from the cities, that is, far from veterinary services. For this reason, there is limited information on clinical findings of dogs infected by L. braziliensis. In a recent epidemiological study conducted in a rural community in northeastern Brazil, a high prevalence $(58.5 \%)$ of L. braziliensis infection was detected in dogs using a conventional polymerase chain reaction (PCR) (DANTAS-TORRES et al., 2010). Considering the limited amount of data in the literature, the aim of this article is to report clinical alterations in 17 L. braziliensis-infected dogs from Pernambuco, Brazil.

Dogs from a rural community located in the municipality of São Vicente Férrer ( $07^{\circ} 35^{\prime} 28^{\prime \prime} \mathrm{S}$ and 35 29' 29” W) were positive by PCR for L. braziliensis in a previous study. All dogs 
were tested by real time PCR for L. infantum, by blood cytology for hemoparasites, and by immunofluorescent-antibody test (IFAT) for anti-Leishmania spp. antibodies (see DANTAS-TORRES et al., 2010). Dogs were physically examined and physical alterations (e.g., skin lesions, weight loss, and alopecia) recorded. Blood samples were withdrawn from the jugular, femoral or cephalic vein and complete blood count was performed. The following parameters were recorded: total red blood cell (RBC) count, hemoglobin concentration (Hgb), packed cell volume (PCV), mean corpuscular volume (MCV), mean corpuscular hemoglobin concentration (MCHC), total white blood cell (WBC) count, differential leukocyte counts, platelet count and serum total protein (JAIN, 1993; KANEKO et al., 1997). This study was part of a project (P.0174-03) approved by the Commission for Ethics in the Use of Animals (CEUA) of the Oswaldo Cruz Foundation (Fiocruz), Brazil.

Out of 20 dogs PCR-positive for L. braziliensis, three were co-infected by other pathogens ( 1 by L. infantum, 1 by Babesia vogeli, and 1 by Hepatozoon canis) and were excluded. The most common hematological abnormalities (Figure 1) found among the $17 \mathrm{~L}$. braziliensis-positive dogs were thrombocytopenia, anemia, low PCV and eosinophilia (Table 1). The anemia was regenerative in seven of $12(58.3 \%)$ dogs. Moreover, in six (50\%) dogs the anemia was normocytic normochromic, in four $(33.3 \%)$ macrocytic normochromic and in two (16.7\%) microcytic normochromic.
In relation to physical alterations, $12(70.6 \%)$ dogs displayed at least one evident physical alteration. Of these, 11 presented skin lesions (e.g., ulcers, desquamation and hyperpigmentation), four had weight loss and two onychogryphosis (Table 1).

In the present study, many L. braziliensis-infected dogs presented hematological values within the normal range. Some dogs presented non-specific hematological and clinical alterations commonly observed in dogs with other diseases, including visceral leishmaniasis. For this reason, the diagnosis of leishmaniasis in dogs should be confirmed using PCR-based tools or by the isolation and subsequent characterization of the parasite using reference isoenzymatic methods. This is important to avoid misdiagnosis with other diseases (e.g., sporotrichosis) with overlapping clinical and laboratory findings (SANTOS et al., 2007). From a public health perspective and considering the control of visceral leishmaniasis, this would be relevant in order to avoid the unnecessary culling of L. braziliensis-infected dogs (MADEIRA et al., 2006). In this regard, the use of specific PCR-based methods should be advisable to distinguish dogs infected by L. braziliensis from those infected by L. infantum (SILVEIRA NETO et al., 2012).

Canine cutaneous leishmaniasis is widespread in South America (DANTAS-TORRES, 2009), being usually prevalent in areas where human cases of the disease have been diagnosed (SOCCOL et al., 2009). However, there is no scientific-based evidence supporting the participation of dogs in the zoonotic transmission cycle of this parasite, which is maintained by small terrestrial mammals

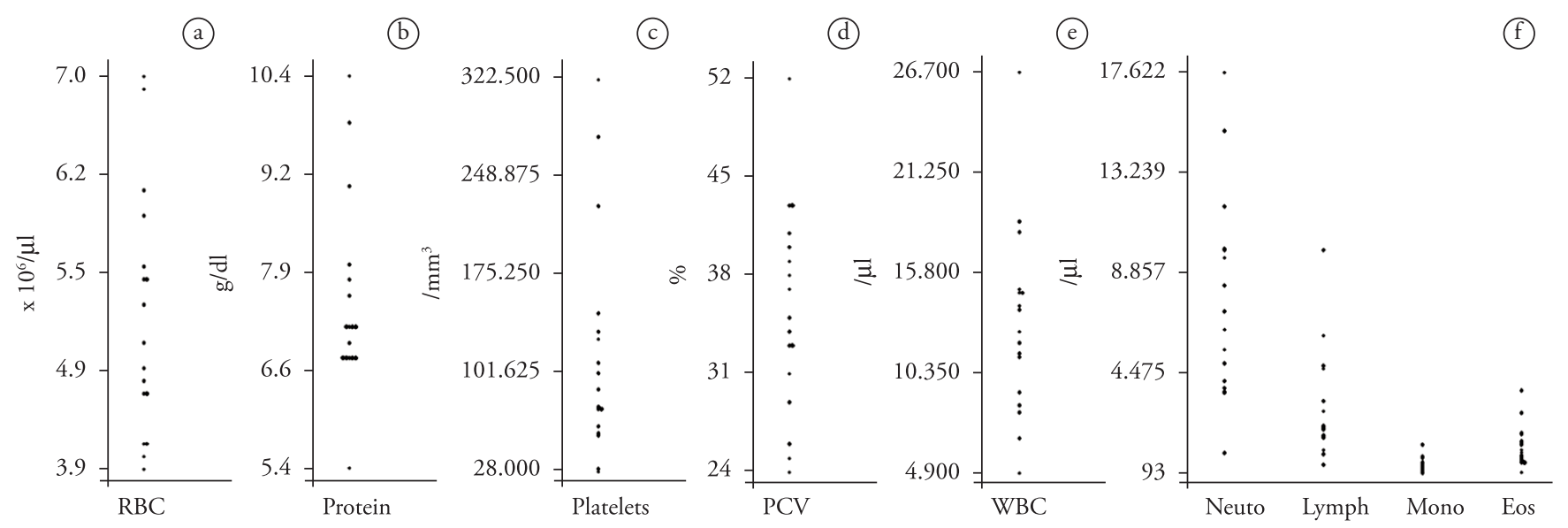

Figure 1. Red blood cells (a), total serum protein (b), platelets (c), packet cell volume (d), white blood cells (e), and neutrophils, lymphocytes, monocytes and eosinophils values (f) recorded for each L. braziliensis-infected dog ( $\mathrm{n}=17$ ). Reference values (KANEKO et al., 1997): RBC,

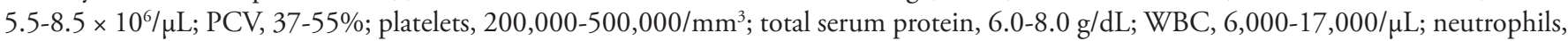

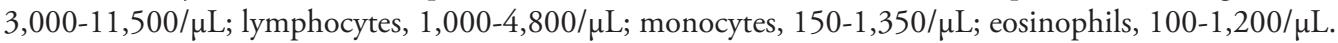

Table 1. Main physical and hematological findings in dogs $(\mathrm{n}=17)$ infected by Leishmania braziliensis, Pernambuco, Brazil.

\begin{tabular}{lcc}
\hline Clinical signs & Number of dogs & Frequency (\%) \\
\hline Thrombocytopenia & 14 & 82.4 \\
Anemia & 12 & 70.6 \\
Skin lesion & 11 & 64.7 \\
Low PCV & 9 & 52.9 \\
Eosinophilia & 7 & 41.2 \\
Weight loss & 4 & 23.5 \\
Onychogryphosis & 2 & 11.8 \\
\hline
\end{tabular}


(BRANDÃO-FILHO et al., 2003). Nevertheless, L. braziliensisinfected dogs might serve as sentinels, that is, indicators for the risk of infection in humans. Incidentally, clinical, histopathological, and serological pictures of canine cutaneous leishmaniasis appear to be similar to those observed in human patients (PIRMEZ et al., 1988). While intralesional injections of $\mathrm{N}$-methylglucamine antimoniate are reputed to be effective (BARBOSA SANTOS et al., 1998), the treatment of canine cutaneous leishmaniosis is not routinely performed in Brazil (DANTAS-TORRES, 2009).

In conclusion, this study suggests that the diagnosis of cutaneous leishmaniasis in dogs cannot be made on a clinical basis only, mainly considering that clinical and hematological findings observed in dogs infected by L. braziliensis might be suggestive, but are not specific.

\section{Acknowledgements}

Thanks to Marcela F. Melo for her help with some field and laboratory activities. This study was supported by the Conselho Nacional de Desenvolvimento Científico e Tecnológico (CNPq) (grant 410481/2006-8) and the Fundação de Amparo à Ciência e Tecnologia do Estado de Pernambuco (FACEPE) (grant APq00522.02/07).

\section{References}

Barbosa Santos EG, Marzochi MC, Conceição NF, Brito CM, Barroso JA, Pacheco RS. N-methylglucamine antimonate ( $\mathrm{SbV}+)$ : intralesional canine tegumentary leishmaniasis therapy. Parasite 1998; 5(2): 175-180. PMid:9754314.

Brandão-Filho SP, Brito ME, Carvalho FG, Ishikawa EA, Cupolillo E, Floeter-Winter L, et al. Wild and synanthropic hosts of Leishmania (Viannia) braziliensis in the endemic cutaneous leishmaniasis locality of Amaraji, Pernambuco State, Brazil. Trans $R$ Soc Trop Med Hyg 2003; 97(3): 291-296. http://dx.doi.org/10.1016/S00359203(03)90146-5

Dantas-Torres F, De Paiva-Cavalcanti M, Figueredo LA, Melo MF, Da Silva FJ, Da Silva AL, et al. Cutaneous and visceral leishmaniasis in dogs from a rural community in northeastern Brazil.
Vet Parasitol 2010; 170(3-4): 313-317. PMid:20227186. http://dx.doi. org/10.1016/j.vetpar.2010.02.019

Dantas-Torres F. Canine leishmaniosis in South America. Parasit Vectors 2009; 2(S1): 1-8. PMid:19426440 PMCid:2679393. http:// dx.doi.org/10.1186/1756-3305-2-S1-S1

Jain NC. Essentials of veterinary hematology. Philadelphia: Lea \& Febiger, 1993.

Kaneko JJ, Harvey JW, Bruss ML. Appendixes. In: Kaneko JJ, Harvey JW, Bruss ML. Clinical biochemistry of domestic animals. 5th ed. New York: Academic Press; 1997. p. 885-906. http://dx.doi.org/10.1016/ B978-012396305-5/50032-4

Madeira MF, Uchôa CM, Leal CA, Macedo Silva RM, Duarte R, Magalhães CM, et al. Leishmania (Viannia) braziliensis in naturally infected dogs. Rev Soc Bras Med Trop 2003; 36(5): 551-555. http:// dx.doi.org/10.1590/S0037-86822003000500002

Madeira MF, Schubach AO, Schubach TM, Pereira SA, Figueiredo FB, Baptista C, et al. Post mortem parasitological evaluation of dogs seroreactive for Leishmania from Rio de Janeiro, Brazil. Vet Parasitol 2006; 138(3-4): 366-370. PMid:16520002. http://dx.doi. org/10.1016/j.vetpar.2006.01.059

Pirmez C, Coutinho SG, Marzochi MC, Nunes MP, Grimaldi Junior G. Canine American cutaneous leishmaniasis: a clinical and immunological study in dogs naturally infected with Leishmania braziliensis braziliensis in an endemic area of Rio de Janeiro, Brazil. Am J Trop Med Hyg 1988; 38(1): 52-58. PMid:3277465.

Santos IB, Schubach TM, Leme LR, Okamoto T, Figueiredo FB, Pereira SA, et al. Sporotrichosis: the main differential diagnosis with tegumentary leishmaniosis in dogs from Rio de Janeiro, Brazil. Vet Parasitol 2007; 143(1): 1-6. PMid:16973286. http://dx.doi. org/10.1016/j.vetpar.2006.08.002

Silveira Neto OJ, Duarte SC, Costa HX, Linhares GF. Design of primer pairs for species-specific diagnosis of Leishmania (Leishmania) infantum chagasi using PCR. Rev Bras Parasitol Vet 2012; 21(3): 304-307. PMid:23070446. http://dx.doi.org/10.1590/S1984-29612012000300024

Soccol VT, De Castro EA, Schnell e Schühli G, De Carvalho Y, Marques E, Fátima Pereira E, et al. A new focus of cutaneous leishmaniasis in the central area of Paraná State, southern Brazil. Acta Trop 2009; 111(3): 308-315. PMid:19482000. http://dx.doi. org/10.1016/j.actatropica.2009.05.013 